Session 2525

\title{
Techniques for Assessing Industrial Projects in Engineering Design Courses
}

\author{
M. Patricia Brackin, J. Darrell Gibson \\ Department of Mechanical Engineering \\ ROSE-HULMAN INSTITUTE OF TECHNOLOGY
}

\begin{abstract}
The benefits of company sponsored student design projects, both to academia and to industry, have been well established recently in symposia and in publications. However, assessing these benefits in order to improve the students' experience can be difficult. Traditionally, design reports alone have been the method by which the students' performance is judged. In this paper, the authors demonstrate the use of company evaluations, oral reports, student self-assessments, as well as design reports to quantify student performance. These methods will be discussed and examples presented showing how the results can be used to improve student performance on industrial projects.
\end{abstract}

\section{INTRODUCTION}

Industrial/Academic partnerships are essential for technological development, regardless of the discipline. The purpose of this paper is to discuss the assessment of these partnerships in order to improve both the students' and the companies' experiences. Traditionally, design reports alone have been the method by which the students' performance is judged. Although a wealth of information is contained within these reports, this information does not address the process that the students used in interacting with their company, nor does a traditional report address all areas of student learning.

This paper discusses the assessment of student projects with industry which are performed as part of the course requirements for Machine Design, a senior mechanical engineering course for four quarter hours of credit. The design project represents $50 \%$ of the course grade and the enrollment is approximately 110. The students work in groups of 3 or 4 and are normally expected to spend approximately 10 hours per week on their projects. Student teams are required to meet with their instructor weekly and submit a written status report. Formalized design methodologies are required. (See for example Pahl and Beitz [1] or Dekker and Gibson [2].) In addition, oral presentations and final written reports are required of each design team, and some companies also invite the teams to their facility for an in-house oral briefing.

\section{DESIGN REPORTS}


Each team must submit a formal design report which counts as $25 \%$ of their course grade. The format for the final written report requires students to include the following sections:

Title Page, Executive Summary, Table of Contents, Nomenclature, Problem Definition, Goals and Constraints, Possible Solutions, Recommended Final Design, Performance Analysis, Conclusions and Recommendations, and Appendices. In addition, students are required to write a letter of transmittal to convey the report to the client. This traditional design report is effective for determining if the students were able to develop appropriate goals and constraints based on their definition of the problem. It is also possible to evaluate if they considered appropriate solutions and if they were able analyze the design sufficiently and communicate the information necessary to produce the design. The overwhelming majority of student groups write adequate to excellent design reports. The design report; however, does not address how well the group communicated with each other, the instructor or the client; and it does not address important lessons that students may have learned as a result of this industrial project.

To encourage students to reflect on their learning, they are asked to include a"lessons learned" section in the Appendix. This section is for any additional information or documentable experience which is not directly relevant to the main body of the report, but which is likely to be useful to someone, someday. They are asked to record anything that they have learned during the present project that might help avoid "glitches" in their next project. Often the lessons learned include at least as much discussion of organizational, personnel, procurement, and scheduling problems as it does discussion of purely technical problems. A sample comment from a student report is shown below.

"We have learned it is very important to supply detailed drawings to the person that is manufacturing the device. Several times, we were contacted by the machine shop with questions because of lack of dimensions. It is also a good idea to sit down with the machine shop to discuss in detail the design. They will be able to tell you if it is possible to fabricate the device. They are also a good source for modifications suggestions that may make the device easier to use." This comment demonstrates that this team has learned that the machine shop personnel are a good resource and that clear communication, both written and verbal is essential. Encouraging students to write about their learning gives them a mode for creative thought and musing, helps them apply what they have learned and push more deeply into a subject. It also requires them to organize what they have learned clearly and coherently. [3]

\section{ORAL REPORTS}


Each team is required to give a group oral report explaining their project to the entire senior class, visiting clients, and any other interested parties. This report must include an introduction of the team members, a statement of the problem, the goals and constraints associated with the project, a brief description of the possible solutions considered, a description of the final design, and conclusions. The oral report represents $25 \%$ of the student's grade in the course, and students are given only 10 minutes for their presentation. This time limit requires the teams to determine the most important aspects of their project and the best way to convey these concepts. At the conclusion of the presentation, students must answer questions from the audience. Teams are graded on how well they convey the essence of their project and how well they are able to answer questions from the audience. As with the written reports, students generally perform adequately on the oral reports. The additional benefits that the teams receive from giving oral presentations is that they must summarize and present the "big picture." These presentations give them experience distilling information and thinking on their feet. From an instructional standpoint, one can determine how well the group understands their project - is their knowledge only superficial or do they have an in-depth understanding? One can ask why they did or did not consider various alternatives. It is also possible to observe how well the group interacts with clients and other students. It is sometimes possible to observe how well the group functions with themselves and the client, but this information is not always available.

\section{STUDENT SELF ASSESSMENT}

Strong self-assessment skills are necessary for students to become mature learners. It is important that students be able to articulate what they know. [4],[5] Each student group is asked to submit their project to the Rose-Hulman Institute of Technology Electronic Portfolio under the Design and Teaming Categories. The skills that they are asked to demonstrate and the results obtained by independent raters are shown in Tables 1 and 2.

Table 1: Senior Students Ability to Demonstrate Teaming Skills

\begin{tabular}{|l|c|c|}
\hline \multicolumn{1}{|c|}{ Performance Criteria for Teaming } & $\begin{array}{c}\text { Number of } \\
\text { Submissions }\end{array}$ & $\begin{array}{c}\text { \% Meeting } \\
\text { Criteria }\end{array}$ \\
\hline 1. Share responsibilities and duties. & 45 & 27 \\
\hline 2. Take on different roles when applicable. & 17 & 0 \\
\hline 3. Analyze ideas objectively. & 44 & 29 \\
\hline 4. Discern feasible solutions. & 42 & 9 \\
\hline 5. Develop a strategy for action. & 40 & 24 \\
\hline 6. Build consensus. & 40 & 22 \\
\hline
\end{tabular}

Table 1 indicates that students were not able to provide evidence that they possessed teaming skills. There are several reasons for this lack of evidence. The first reason is that several students did not choose appropriate material to submit. There was a tendency to submit their design report 
to meet every single performance criteria. However, a professional report does not specify which team member played which roles. Secondly, there was some confusion as to what evidence is necessary to demonstrate that the given performance criteria has been met. This was an institute wide problem and has been addressed by developing rubrics for all criteria. For example, the "share responsibilities and duties" rubric under teaming has been defined as follows:

Description: The student should describe the roles of each team member and indicate how sharing responsibilities facilitates project completion.

Example: In a team member evaluation, a student might list the tasks performed by each member of the group.

Not Acceptable: To list only the student's own responsibilities.

Finally, there were seniors who did not have good teaming skills. The major problems these students encountered were not dividing tasks and not organizing the group. To help improve these students' skills, lectures were provided on team organization and scheduling. In addition, teams are asked about their teaming in weekly meeting and asked to indicate which tasks are assigned to team members in their weekly status reports.

As shown in Table 2, the results for the design criteria are considerably higher than the teaming results and this would indicate, therefore, that there is a need for improvement. Analysis of the submissions indicated that students also tended to submit inappropriate materials as evidence for the design category. For example, every group was required to send their report to their company using a letter of transmittal. Students did not receive a grade in the class until this letter and the report had been submitted to the company. Many students submitted a copy of their design report for criterion 7 (Present and transfer the product or process and documentation to the client.) rather than submitting their letter of transmittal.

Although criterion 5 (Test and refine the product or process implementation until the product or process design specifications are met or exceeded. ) received a low percentage, (24) this is not a cause for concern because of the nature of the projects. The majority of the projects are NOT design, test, and build. Often companies ask for multiple suggestions for improving a product or process, and the end deliverable to the company is a conceptual design.

There is some concern that criterion 4 (Carry out a detail-level product or process design using appropriate design tools and methodologies.) received a low percentage. (32) The cause of this lower rating is currently under study.

It was gratifying that independent raters agreed that $89 \%$ of the reports met criterion 6. (Document the finished product or process as appropriate for the discipline according to standard practice.) Company evaluations also agreed that the majority of the written reports communicated results and recommendations as discussed in the following section.

Table 2: Senior Students Ability to Demonstrate Design Skills

\begin{tabular}{|l|c|c|}
\hline Performance Criteria for Design & $\begin{array}{c}\text { Number of } \\
\text { Submissions }\end{array}$ & $\begin{array}{c}\% \text { Meeting } \\
\text { Criteria }\end{array}$ \\
\hline
\end{tabular}

Proceedings of the 2001 American Society for Engineering Education Annual Conference \& Exposition Copyright (C) 2001, American Society for Engineering Education 


\begin{tabular}{|l|c|c|}
\hline 1. Elicit customer needs and constraints. & 60 & 50 \\
\hline $\begin{array}{l}\text { 2. Develop a product or process design } \\
\text { specification that addresses appropriate issues } \\
\text { (such as initial costs, operating costs, power, } \\
\text { size, testability, reliability, serviceability, } \\
\text { manufacturability, controllability, schedule, } \\
\text { ergonomics, safety, and environmental issues). }\end{array}$ & 39 & 72 \\
\hline $\begin{array}{l}\text { 3. Carry out a conceptual product or process } \\
\text { design by generating multiple solutions that } \\
\text { address the issues above, evaluating the } \\
\text { feasibility of the solutions, and choosing the } \\
\text { appropriate solution. }\end{array}$ & 36 & 69 \\
\hline $\begin{array}{l}\text { 4. Carry out a detail-level product or process } \\
\text { design using appropriate design tools and } \\
\text { methodologies. }\end{array}$ & & \\
\hline $\begin{array}{l}\text { 5. Test and refine the product or process } \\
\text { implementation until the product or process } \\
\text { design specifications are met or exceeded. }\end{array}$ & 38 & 32 \\
\hline $\begin{array}{l}\text { 6. Document the finished product or process as } \\
\text { appropriate for the discipline according to } \\
\text { standard practice. }\end{array}$ & 46 & 24 \\
\hline $\begin{array}{l}\text { 7. Present and transfer the product or process } \\
\text { and documentation to the client. }\end{array}$ & & \\
\hline
\end{tabular}

\section{COMPANY EVALUATIONS}

In order to determine the clients' opinion of student performance, questionnaires are distributed to all participants. The surveys ask respondents to rank students according to the following scale: 5 - excellent; 4 - acceptable; 3 - fair; 2 - not too good; 1 - no opinion or not applicable. Clients are also asked for any additional comments or suggestions. Typical results for each question are shown in Table 3.

An examination of Table 3 would indicate that those corporate sponsors perceived that the vast majority of the written reports communicated the results and recommendations adequately. The two lowest averages indicated were the benefit to the company and the students' communication with the company. The lower rating in both of these categories may well be attributed to poor communication. Some of the written comments indicated that the clients felt that the students did not understand the problem properly or that some student groups did not discuss alternatives with the company. In one case a group pursued a solution that was impossible because of constraints that the students did not define properly. 
It is planned to further improve communications with each company by requiring each team to submit an interim report to their company which will serve as a preliminary design review. This report will require students to detail their alternatives and support their proposed solution. It will also allow the company to give formal feedback to the students about their progress. This additional feedback should also improve the benefit of the project to the company.

Table 3: Industry Design Project Evaluations by Sponsors

\begin{tabular}{|l|c|c|c|c|c|c|}
\hline Question/Ranking & 5 & 4 & 3 & 2 & 1 & Avg. \\
\hline $\begin{array}{l}\text { 1. How well does the written report } \\
\text { communicate results \& recommendations }\end{array}$ & 5 & 5 & 1 & 1 & 0 & 4.2 \\
\hline $\begin{array}{l}\text { 2. How well did students communicate with } \\
\text { you during the project? }\end{array}$ & 1 & 6 & 3 & 2 & 0 & 3.5 \\
\hline $\begin{array}{l}\text { 3. How good was the students' grasp of the } \\
\text { general problem? }\end{array}$ & 5 & 3 & 2 & 2 & 0 & 3.9 \\
\hline $\begin{array}{l}\text { 4. What was your opinion of the methodology } \\
\text { the students used to approach and solve the } \\
\text { problem? }\end{array}$ & 5 & 3 & 3 & 1 & 0 & 4.0 \\
\hline $\begin{array}{l}\text { 5. Please estimate the benefit of this project to } \\
\text { your company. }\end{array}$ & 2 & 3 & 4 & 3 & 0 & 3.3 \\
\hline $\begin{array}{l}\text { 6. Please estimate the educational benefit to } \\
\text { the students. }\end{array}$ & 3 & 6 & 2 & 1 & 0 & 3.8 \\
\hline
\end{tabular}

\section{CONCLUSIONS}

Traditional design reports are appropriate for assessing students' ability to develop appropriate goals and constraints based on their definition of the problem. Design reports are also appropriate for evaluating the teams consideration of appropriate solutions, the sufficiency of their analyses supporting the design, and the communication of the information necessary to produce the design. The design report does not normally address the team's interactions within the team and with the client, it is a static document that can not be queried. Use of oral reports, student self-assessment and independent review, and company evaluations gives a more complete picture. Using the information obtained from these other instruments, several areas of concern were identified such as: students' teaming skills, students' ability to elicit customer needs and constraints, and communications between student teams and the clients. To address these areas of concern, some changes have been implemented. These changes include instruction on team management, weekly feedback concerning team dynamics, and initiation of a preliminary design review.

This paper has presented four distinct techniques for assessing student industrial design projects; namely, Design Reports, Oral Reports, Student Self Assessment, and Company 
Evaluations. These four metrics will provide broad assessments of the design projects. It should be kept in mind however that these data should be used in conjunction with the subjective judgments of the design faculty members for final evaluations.

\section{BIBLIOGRAPHY}

[1] Pahl, G. and Beitz, W., Engineering Design: A Systematic Approach, Edited by Ken Wallace, Springer-Verlag, The Design Council, 1988.

[2] Dekker, D., and Gibson, J. D., "Learning Design in a College Setting”, International Conference on Engineering Design, Tampere, Finland, August, 1997.

[3] Walvoord, B., "Helping Students Write Well: A Guide for Teachers in All Disciplines", The Modern Language Association of America, New York, 1986.

[4] Process Education Teaching Institute Handbook, Pacific Crest, Corvalis, 1999.

[5] Gibson, J.D. and Brackin, M.P., "Techniques for the Implementation and Administration of Industrial Design

Projects for Engineering Design Courses", Proceedings of the ASEE Annual Conference, Charlotte, NC, 1999.

\section{BIOGRAPHICAL INFORMATION}

M. PATRICIA BRACKIN is an Associate Professor of M.E. at Rose-Hulman Institute of Technology where she teaches design, controls, graphics, and mechanical measurements. Her BS and MS are from the University of Tennessee in Nuclear Engr and her Ph.D. is from Georgia Institute of Technology in ME. She has also been an Associate Professor at Christian Brothers University. Her industrial experience includes Oak Ridge National Laboratories and Chicago Bridge and Iron. She is a registered PE.

J. DARRELL GIBSON is a Professor of M.E. at Rose-Hulman Inst of Tech where he teaches design, noise control, and structural mechanics. His BS and MS are from Purdue in Aero Engr and his Ph.D. is from the Univ of New Mexico in ME. He has also been an Associate Professor at the Univ of Wyoming and a Visiting Professor at Colorado State Univ. His industrial experience includes General Dynamics Corp, J.I Case Co, Sandia Labs, NASA/Langley Research Center, and NASA/Jet Propulsion Lab. He is a registered PE. 